\title{
Residual Biomass from Food Processing Industry in Cameroon as Feedstock for Second-generation Biofuels
}

\author{
Teodor Vintila, ${ }^{a}$ Ioana Ionel, ${ }^{\mathrm{b}, *}$ Tagne Tiegam Rufis Fregue, ${ }^{\mathrm{c}}$ Adriana Raluca Wächter, \\ Calin Julean, ${ }^{\mathrm{a}}$ and Anagho Solomon Gabche ${ }^{\mathrm{c}}$
}

\begin{abstract}
The yields in bioconversion of residues produced in the Cameroon food industry to liquid and gaseous biofuels were evaluated and the potential of these residues as feedstock for renewable energy production in Cameroon were assessed. Residues generated after processing avocado, cocoa, and peanut crops were converted at laboratory-scale to second-generation gaseous biofuels (biogas) and liquid biofuels (ethanol). Mechanical (milling), thermal-chemical (steam-NaOH), and microwave pretreatments were applied before hydrolysis of biomass using cellulolytic enzymes. Cellulosic sugars production potential was also assessed. The energy conversion rate was higher when anaerobic digestion technology was applied to convert the tested biomass to methane. The total Cameroon potential under anaerobic digestion technology is over $330,000 \mathrm{~m}^{3}$, which represents $28 \%$ from oil consumption or $5.39 \%$ from electricity consumption when lignocellulosic ethanol technology was applied. The national potential was assessed up to $200,000 \mathrm{~kg}$, representing $17 \%$ from oil consumption in transport or $3.19 \%$ from electricity consumption. Overall, the share of energy potential of the tested residual biomass is important when compared to fossil fuel consumption in Cameroon and represents an important potential feedstock for electricity production.
\end{abstract}

Keywords: Avocado; Cocoa; Peanut residues; Biogas; Bioethanol; Energy; Cameroon

Contact information: a: Department of Biotechnology, Banat's University of Agricultural Science and Veterinary Medicine "King Michael I of Romania," Timisoara, Calea Aradului Street, No. 119, 300645 Romania; b: Department of Mechanics, Politechnica University from Timisoara, Mihai Viteazu Street, No. 1, 300222 Romania, c: Research Unit of Noxious Chemistry and Environmental Engineering, Department of Chemistry, Faculty of Science, University of Dschang, P.O. Box 67, Dschang, Cameroon;

*Corresponding author: tvintila@animalsci-tm.ro

\section{INTRODUCTION}

The African population has low accessibility to grid energy, which is statistically becoming lower as the population growth rate becomes higher than the energy development rate. In sub-Saharan Africa, less than $69 \%$ of the population has access to electricity (Girod 1994). Like many countries in sub-Saharan Africa, Cameroon faces a large problem of accessing electricity. In Cameroon, it is estimated that 3 million of its 20 million inhabitants have access to electricity (under $20 \%$ from the total population). The overall electricity production in Cameroon is approximately $305 \mathrm{KWh}$ per inhabitant for a gross electricity consumption of 6.2 TWh (Nkue and Njomo 2009). Electricity is mainly produced by hydropower, which accounts for $73.3 \%$ of production, followed by thermal power plants $(25.6 \%)$, and lastly biomass, which accounts for only $1 \%$. However, Africa has abundant renewable energy resources, particularly from different types of biomass and agricultural and food processing organic residues that are regarded as 
feedstock for biofuels production. One example is Cameroon, the leading avocado producer in Central Africa. The national avocado production in Cameroon averages approximately 120 kilotons annually and a substantial amount of this production is concentrated in the western region. The main product for the market after processing these fruits is avocado oil, which creates a large amount of avocado seed waste. Approximately 28,800 tons of avocado residues are released into the environment each year (Azap 2008; NAVTI Fondation Canada 2016). Natural decomposition of this type of residual biomass takes several years if it is not burned in place after drying. Both disposal methods cause environmental pollution and the loss of important energy resources. Similar issues arise as a result of the production and processing of other agri-food products, such as cocoa and peanuts. The processing of cocoa generates 150 kilotons of waste annually, while peanut processing generates almost 200 kilotons annually (Meughoyi 2018). Smart resource management of these considerable amounts can be key to solving energy shortages in the area. This study aims to answer the following questions: Are these resources suitable for biofuels production?; what type of process should be applied to convert them into biofuels?; how much energy can be produced from these types of biomass?; and what portion from the actual energy consumption in Cameroon can be covered by the energy produced by applying the waste conversion technologies approached in this study?

To generate energy, the lignocellulosic biomass can be burned directly or after its conversion into solid fuel (e.g. biochar), liquid fuel (bioethanol, biodiesel, bio-oil), or gaseous fuel (e.g. biogas). Ethanol presently has the largest market due to its use, not only as primary fuel, but as a chemical feedstock or fuel additive as well. Anaerobic digestion to produce bio-methane (biogas technology) has the potential to yield more energy than other current type of bio-fuels (Kumar et al. 2008) and can be applied to a wide range of residual biomass. Among various biofuels, the production of bioethanol can be the most attractive, but only if the state-of-art technology becomes implemented, which uses cellulosic pretreated feedstock and combines the production of ethanol with production of other valuable products (e.g. fertilizer) together with recycling of wastes (Ioelovich 2015). From this point of view, biogas technology is the most appropriate.

In this study, laboratory-scale research was applied to demonstrate the production of liquid and gaseous biofuels via industrial biotechnologies (bioethanol and biogas technologies) from residues produced in the Cameroon food industry. Additionally, this study assesses the potential of these residues to be considered as feedstock for renewable energy production in Cameroon.

\section{EXPERIMENTAL}

\section{Materials}

\section{Lignocellulosic feedstock}

The feedstock used in this study for biofuel production consisted of the wastes left over after processing agricultural products specific for the Cameroon agro-industry: avocado seeds (Persea americana), cocoa pods (Theobroma cocoa), and peanut shells (Arachis hypogea). The composition of the residual lignocellulosic biomass was analyzed according to standard procedures: dry matter, organic dry matter, and cellulose by NREL procedures (Sluiter et al. 2005). The total crude fiber content was determined according to the Foss Tecator method ASN 3801 (EN ISO 13906 2008) and is presented in Table 1. 
Table 1. Main Composition of the Residual Biomass

\begin{tabular}{|c|c|c|c|c|}
\hline Biomass & $\begin{array}{c}\text { Dry Matter } \\
(\%)\end{array}$ & $\begin{array}{c}\text { Organic } \\
\text { Dry Matter } \\
(\%)\end{array}$ & $\begin{array}{c}\text { Total Fibers (\% from } \\
\text { DM) }\end{array}$ & $\begin{array}{c}\text { Cellulose } \\
(\% \text { from } \\
\text { DM })\end{array}$ \\
\hline Avocado seeds & 85.79 & 71.10 & 15.65 & 7.74 \\
\hline Cocoa pods & 84.27 & 63.22 & 63.41 & 18.6 \\
\hline Peanut shells & 88.49 & 71.60 & 81.97 & 40.5 \\
\hline
\end{tabular}

\section{Cellulolytic enzymes}

Hydrolysis of the cellulose and hemicellulose was catalyzed using a mixture of two commercial cellulolytic products (Novozymes, Bagsværd, Denmark): NS22192 and Cellic CTec2. While the enzymatic products were stored in the laboratory using refrigeration, the enzymatic activity may have changed during the time between when the materials were acquired and their use as the catalysis for the hydrolysis of lignocellulosic biomass. Consequently, the enzymatic activity of the products was assessed upon hydrolysis. The method described by Ghose and agreed by IUPAC and NREL was applied to assess the enzymatic activity of the products (Ghose 1987). The enzymes load indicated by the provider was 15 IU (international units) per gram of cellulose. After measurement of the cellulolytic activity, the enzymes were dosed accordingly.

\section{Methods}

Pretreatment of lignocellulosic residues - Mechanical pretreatment

In the lignocellulosic complex, cellulose and hemicelluloses are covered by lignin, a recalcitrant chemical blocking the access of the celluloses to the cellulosic polysaccharides. To facilitate the access of cellulolytic enzymes to the substrate, the lignocellulosic material was initially washed twice with distilled water to remove dust and subsequently dried at $105^{\circ} \mathrm{C}$ for $24 \mathrm{~h}$ to remove the moisture content. Then, the dried raw material was micronized, i.e., disrupted to small particles under $1 \mathrm{~mm}$ in size. The biomass was milled in a cutting miller (GRINDOMIX GM200; Retsch GmbH., Haan, Germany), sieved to the size of $90 \mu \mathrm{m}$ to $1000 \mu \mathrm{m}$, and stored at an ambient temperature until use.

\section{Thermal-chemical pretreatment}

Other techniques applied worldwide to facilitate the access of cellulolytic enzymes to the substrate consist of degrading the lignocellulosic complex using an alkaline/steam pretreatment method. The biomass was suspended in a $1 \%$ sodium hydroxide $(\mathrm{NaOH})$ solution in the proportion of $25 \mathrm{~g}$ biomass dry matter to $100 \mathrm{~mL}$ $\mathrm{NaOH}$ solution. The samples were analyzed in triplicate to minimize errors. The steam pretreatment was performed in a 13-L autoclave (CALORIS R, Bucharest, Romania), with a total capacity of $3.25 \mathrm{~kg}$ of biomass per charge. The thermal pretreatment was applied to the lignocellulosic waste suspensions in the alkaline solution at $140{ }^{\circ} \mathrm{C}$ for 10 min (Gonzalez et al. 2011; Xu et al. 2018).

\section{Microwave pretreatment}

In the third pretreatment type, the biomass was suspended in the same alkaline solution in similar proportions as in the thermal-chemical pretreatments. In this case, the 
biomass suspensions were treated in a 30/30/20 (Length/Width/Height) microwave oven (Samsung TDS; Samsung Electronics, Suwon, South Korea) with a total capacity of 2 $\mathrm{kg} / \mathrm{charge}$, at 300 watts for $25 \mathrm{~min}$. These parameters (time and power in microwave treatments) were set before in previous research regarding microwave pretreatments of residual lignocellulosic biomasses (Vintila et al. 2019). The objective of the pretreatment was to create pores in the strong lignin polymer covering the cellulose and hemicellulose to facilitate the access of the cellulolytic enzymes to the specific substrates and make the biomass more susceptible for enzymatic hydrolysis.

After thermal-chemical and microwave pretreatments, the alkalinity of the samples was neutralized with a $1 \%$ sulfuric acid $\left(\mathrm{H}_{2} \mathrm{SO}_{4}\right)$ solution until reaching a $\mathrm{pH}$ of 5. To avoid $\mathrm{pH}$ variations, the process was conducted under continuous agitation. The samples were washed afterwards using a volume of water at least five times higher than the biomass suspension. During the washing phase, the free reducing sugars (pre-existing in the biomass and possible to be released during pretreatment) were removed from the biomass. The liquid was separated from the biomass using a filtration system including a vacuum pump (UNIJET I; UniEquip, Planegg, Germany) and Buchner funnel. The wet, pretreated biomass was stored by refrigeration until its use as feedstock for biogas and bioethanol production.

\section{Cellulosic sugars production potential}

The enzymatic hydrolysis of the pretreated biomass was completed using NS22192 and Cellic CTec2 as biocatalysts. The reaction was performed in Erlenmeyer flasks in aseptic conditions (sterilization $20 \mathrm{~min}$ at $121^{\circ} \mathrm{C}$ ). Each flask contained $50 \mathrm{~mL}$ citrate buffer $0.05 \mathrm{M}$, at a $\mathrm{pH}$ of 5 , and a corresponding quantity of biomass to obtain suspensions containing 3\% dry matter. The volume of the buffer allowed efficient agitation of the reaction mixture in the flask and entire immersion of the biomass into the buffer. To facilitate the contact between the enzymes and the substrate, the surfactant Tween 80 was added in each batch at a concentration of $5 \mathrm{~g} / \mathrm{L}$. Flasks covered with cotton plugs were autoclaved at $121{ }^{\circ} \mathrm{C}$ for $20 \mathrm{~min}$ for sterilization. Cellulase enzymes were added to each batch in a concentration of 15 units/g of cellulose. A final $\mathrm{pH}$ check was made before incubation of the samples at $50{ }^{\circ} \mathrm{C}$ under continuous shaking at 150 rpm. The flasks were closed with cotton plugs to avoid evaporation, spills, and the access of microorganisms into the reaction media. The hydrolysis was performed for $48 \mathrm{~h}$. The released sugars were analyzed before the addition of enzymes and after $24 \mathrm{~h}$ and $48 \mathrm{~h}$ of incubation. The withdrawn samples were centrifuged at $10000 \mathrm{rpm}$ for $5 \mathrm{~min}$. The content of reducing sugars was assayed in a supernatant through measuring the absorbance at $540 \mathrm{~nm}$ against a blank, in accordance to a standard curve (D-glucose solutions 0 to $10 \mathrm{~g} / \mathrm{L}$ ) via an ultra violet visible (UV-VIS) spectrometer (Gold S54 Spectrumlab UV-VIS spectrophotometer; UniEquip, Planegg, Germany) and 3,5dinitrosalicylic acid (DNS) as the reagent (Miller 1959). All assays were performed in triplicate. The solid phase, representing the un-hydrolyzed biomass, was dried at $105{ }^{\circ} \mathrm{C}$. The hydrolysis rate of the biomass was the difference between the quantity of the biomass subject to hydrolysis and the biomass found un-hydrolyzed in the flasks and reported as a percentage.

\section{Bioethanol production potential}

The sugar fermentation obtained through hydrolysis of the lignocellulosic biomass to ethanol was conducted in a laboratory setup (Fig. 1) and was composed of: 
1. Incubator (GFL 3031; Gesellschaft für Labortechnik, Burgwedel, Germany) to maintain the temperature at an optimal value for yeast activity;

2. Glass flasks of 1-L capacity, provided with ethanol and $\mathrm{CO}_{2}$ sensors (BlueSens, Herten, Germany);

3. Gas counters (Ritter, Bochum, Germany) to measure the volume of $\mathrm{CO}_{2}$ released;

4. Junction box for data acquisition from gas sensors, including BACCom software for data processing (BlueSens, Herten, Germany);

5. Near-infrared (NIR) system (Alcolyzer, Anton Paar, Graz, Austria) to measure ethanol concentration in fermentation liquids;

6. A computer for data acquisition.

Each of the three glass flasks contained $500 \mathrm{~mL}$ of fermentation medium composed of one type of pretreated biomass (wastes of avocado, cocoa, or peanuts), $10 \%$ dry matter, peptone $2 \%$, and yeast extract $1 \%$ as yeast nutrients, polyoxyethylene (80) sorbitan monooleate (Tween 80 ) $0.5 \%$ as the surfactant, and citrate buffer $0.05 \mathrm{M}, \mathrm{pH} 5$, up to $500 \mathrm{~mL}$ per flask. Flasks covered with plastic were autoclaved at $121{ }^{\circ} \mathrm{C}$ for $20 \mathrm{~min}$ for sterilization. After cooling, the celluloses were added according to the enzymatic activity of the products and obtained an enzyme load of $15 \mathrm{IU} / \mathrm{gram}$ of cellulose.

The first phase in the production of lignocellulosic ethanol was the hydrolysis of the cellulose to produce fermentable sugars. This phase was conducted for $48 \mathrm{~h}$ at $50{ }^{\circ} \mathrm{C}$. The samples were harvested to analyze their sugar contents.

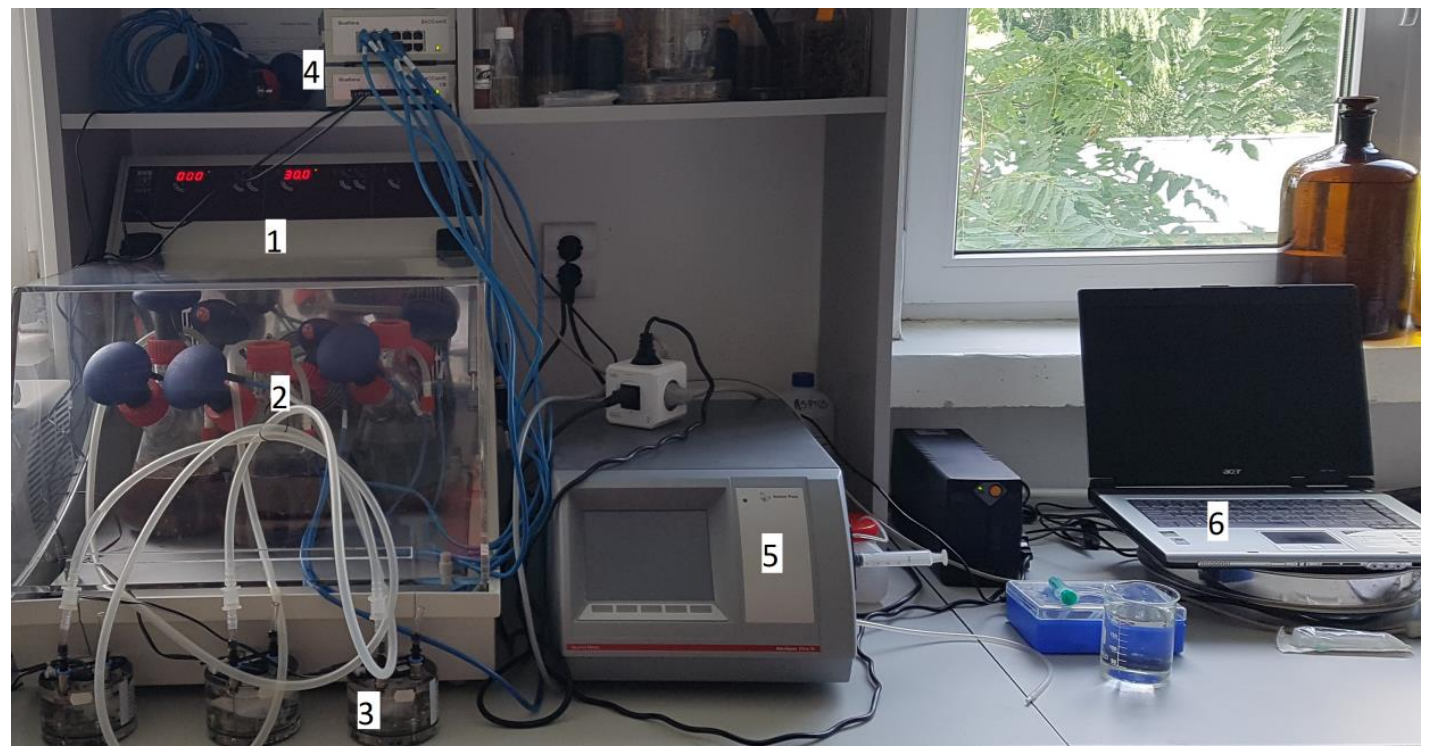

Fig. 1. General overview of ethanol fermentation system: 1) incubator, 2) glass flasks with sensors, 3) gas counters, 4) junction box, 5) NIR system, and 6) computer

The second phase consisted of the fermentation of sugars released during the hydrolysis phase. The temperature of the flasks was decreased to $30{ }^{\circ} \mathrm{C}$, and Saccharomyces cerevisiae was added at an inoculation rate of $0.1 \mathrm{~g}$ dried yeast per 100 $\mathrm{mL}$ fermentation medium. The yeast was provided by Protect Consult (Bucharest, Romania) and was an acid-tolerant strain that is active in fermentation media at low $\mathrm{pH}$ values as low as 2.5. The fermentation was monitored, and the activity of the microorganisms was observed through BlueSens sensors (Herten, Germany) attached to 
the fermentation flasks. The samples were harvested daily to analyze the decrease of reducing sugars (DNS method via Miller 1959) and the increase of ethanol concentration (NIR system Alcolyzer, Anton Paar, Graz, Austria).

\section{Biomethane production potential}

The assessment of the biochemical methane potentials (BMP) of the three residual biomass types was made in the Laboratory of Industrial Microbiology and Biotechnology from the University of Agricultural Science in Timisoara, Romania. The equipment used was the Automatic Methane Potential Test System-AMPTS II (Bioprocess Control, Lund, Sweden). The biomass was digested in 600-mL capacity bioreactors from AMPTS II using inoculum from an active on-farm biomass plant. The BMP of each sample was made in triplicate, according to VDI 4630 (2006) standard protocol issued by the Association of German Engineers and to the AMPTS II operation manual (Bioprocess Control A.B. 2016). The laboratory setup of the equipment is presented in Fig. 2.

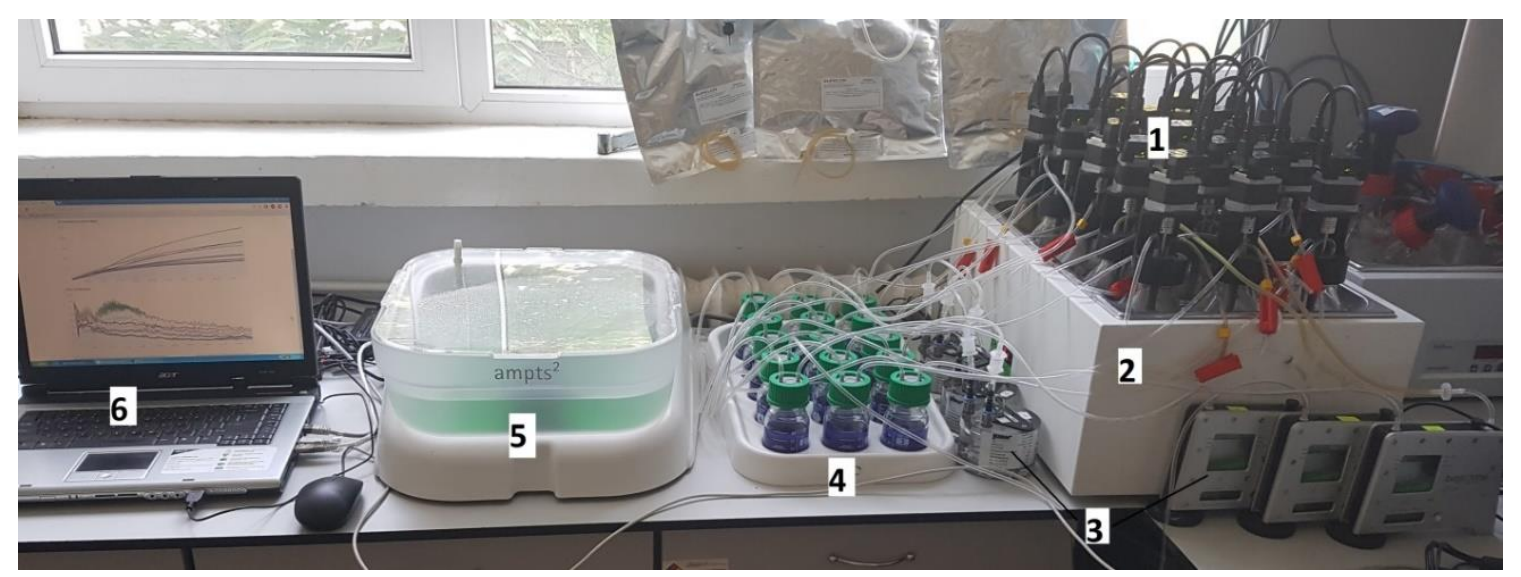

Fig. 2. General overview of AMPTS system: 1) bioreactors/digesters, 2) incubation unit, 3) gas counters, 4) $\mathrm{CO}_{2}$ absorption unit, 5) methane measuring unit, and 6) laptop for data recording

Each bioreactor was fed with a mixture of inoculums, biomass, and water to obtain slurries containing a maximum of $10 \%$ dry matter and an inoculums / substrate rate of 2:1 as organic dry matter content. After filling the bioreactors and checking the gas-tightness, the head space in each bioreactor was flushed for approximately $60 \mathrm{~s}$ with a gas mixture of $45 \% \mathrm{CO}_{2}$ and $55 \% \mathrm{~N}_{2}$. The biomass was anaerobically digested in the batch system in mesophilic conditions at $37^{\circ} \mathrm{C}$. The BMP test was ceased when the daily methane yield was less than $1 \%$ from the total yield.

The following batches of BMP tests were performed in this study for the residual biomass of the avocado, cocoa, and peanuts:

A. Milled (micronized) biomass;

B. Milled, steam-alkaline pretreated;

C. Milled, steam-alkaline pretreated, addition of cellulolytic enzymes.

Assessment of gross calorific value

An important property of the residual materials was the heating value. This parameter demonstrated the effectiveness of using these materials as fuel and to evaluate the energy obtained by their conversion to liquid (ethanol) and gaseous (methane) biofuels. The gross calorific value is defined as the quantity of heat released by the 
complete burning of a unit mass of fuel with oxygen at a constant volume process (ASTM D3286 1996). The gross calorific value of the solid biomass was determined in an IKA C1 bomb calorimeter (IKA Werke GmbH \& Co., KG, Staufen, Germany) and obtained through burning a known mass of the sample, in a high-pressure oxygen atmosphere, within a stainless-steel pressure vessel (bomb). The heat released by this combustion was transferred to the water within the calorimeter and the resulting temperature change of the water was used to calculate the amount of heat transfer (BS ISO 1928 2009).

\section{RESULTS AND DISCUSSION}

\section{Activity of Cellulases}

The commercial cellulolytic products NS22192 and Cellic CTec2 were stored in a laboratory refrigerator, and the enzymatic activity was assessed using the Ghose method (Ghose 1987). First, the activity was established for each product at $50{ }^{\circ} \mathrm{C}$ and a $\mathrm{pH}$ of 5 , as indicated by the provider as the optimal reaction conditions. In these conditions, activities of 296.12 FPU/mL product were observed for NS22192 and $252.25 \mathrm{FPU} / \mathrm{mL}$ product for Cellic CTec2. The cellulolytic activity is expressed in FPU, representing filter paper units (Ghose 1987). Furthermore, the mixture activity obtained by the two enzymatic products (mixture 1:1) was tested at $\mathrm{pH}$ and temperatures higher and lower than optimal conditions recommended by provider, respectively.

Table 2. Enzymatic Activity of the Cellulolytic Products Used for Hydrolysis of Residual Biomass

\begin{tabular}{|c|c|c|c|c|c|c|c|c|c|c|c|c|}
\hline & \multicolumn{10}{|c|}{ Reaction Conditions } \\
\hline pH & \multicolumn{3}{|c|}{4.5} & \multicolumn{3}{c|}{5} & \multicolumn{3}{|c|}{5.5} & \multicolumn{3}{c|}{7} \\
\hline Temp. & 37 & 45 & 50 & 37 & 45 & 50 & 37 & 45 & 50 & 37 & 45 & 50 \\
\hline $\begin{array}{c}\text { Enzymatic } \\
\text { Activity } \\
\text { (FPU/mL) }\end{array}$ & 103 & 228 & 266 & 156 & 261 & 294 & 79 & 212 & 217 & 56 & 132 & 165 \\
\hline $\begin{array}{c}\text { Activity } \\
\text { Compared to } \\
\text { Recommended } \\
\text { Conditions (\%) }\end{array}$ & 35 & 66 & 86 & 53 & 83 & 100 & 27 & 57 & 60 & 19 & 45 & 56 \\
\hline
\end{tabular}

The data in Table 2 indicated that a temperature of $50{ }^{\circ} \mathrm{C}$ and $\mathrm{pH}$ of 5 were the optimal conditions for the activity of the enzymatic mixture to hydrolyze the cellulose and release reducing sugars. The activity decreased at a higher $\mathrm{pH}$ and lower temperature. The activity represented the quantity of reducing sugars released in 1 min of reaction. Even at lower temperatures and a higher $\mathrm{pH}$, the enzymes were active and released lower amounts of reducing sugars per minute. In other words, the enzymatic mixture transformed the cellulose in normal conditions of anaerobic digestion and had the ability to release reducing sugars for the entire domain of the $\mathrm{pH}$ and temperature tested (Table 2). This combination with cellulolytic activity can be used as an efficient and versatile co-catalyst in anaerobic digestion acting in synergism with the microorganisms in the hydrolysis step of the residual biomass. The low kinetic of the hydrolytic enzymes reaction in the conditions encountered in anaerobic digestion was a positive aspect. The 
availability of sugars in high concentrations in a short time led to higher fermentation rates in the acidogenesis phase of the anaerobic digestion, which resulted in a decrease of $\mathrm{pH}$ and methanogenic bacteria inhibition. From this point of view, low enzyme kinetics in anaerobic digestion is a positive aspect. For the sugar production of the secondgeneration biochemicals production, the residual biomass hydrolysis was carried out at the optimal conditions: a temperature of $50^{\circ} \mathrm{C}, \mathrm{pH}$ of 5 , and enzyme loading of $25 \mu \mathrm{L}$ of enzymatic mixture per gram of cellulose (approximately 15 FPU/gram cellulose).

\section{Cellulosic Sugars and Ethanol Production Potential}

The enzymatic hydrolysis of mechanical, thermal-chemical, and microwave pretreated biomass was realized using an enzymatic mixture of NS22192 and Cellic $\mathrm{CTec} 2$ as biocatalysts. The initial suspensions of the raw biomass contained $100 \mathrm{~g}$ biomass per litre of citrate buffer $\mathrm{pH} \mathrm{5}$, and reducing sugars were released before adding enzymes. Data in Table 3 show the concentrations of free, soluble reducing sugars, particularly in avocado residues $(121.7 \mu \mathrm{g} / \mathrm{mg}$ biomass as dry matter). The initial sugar contents in the cocoa pods was half and the peanuts were approximately four times lower than in the avocado seeds (Table 3). During thermal-chemical and microwave pretreatments, the soluble sugars contained in the biomass were removed by the alkaline solution used for treating lignin, the sulfuric acid solution was used for neutralization, and the water used for washing. The outcomes of the sugar yields obtained after biomass hydrolysis through different pretreatments were slightly different in the three types of biomass. Applying the steam pretreatment resulted in an increase of sugar yields in the avocado and cocoa and lower yields in the peanut residues. Applying microwave pretreatments resulted in a slight increase to sugar yields in the peanuts and lower yields in the avocado and cocoa residues compared to the mechanical pretreatment.

Table 3. Sugar and Ethanol Yields

\begin{tabular}{|c|c|c|c|c|c|c|c|c|c|}
\hline Biomass & \multicolumn{3}{|c|}{ Avocado } & \multicolumn{3}{c|}{ Cocoa } & \multicolumn{3}{c|}{ Peanut } \\
\hline Pretreatment & Mi & St & Mw & Mi & St & Mw & Mi & St & Mw \\
\hline $\begin{array}{c}\text { Initial Sugars } \\
\left(\mathrm{mg.g}^{-1}\right)\end{array}$ & 121.7 & - & - & 65.2 & - & - & 38.7 & - & - \\
\hline $\begin{array}{c}\text { Sugars } \\
\text { Yields } \\
\left(\mathrm{mg.g}^{-1}\right)\end{array}$ & 336.4 & 449.8 & 237.9 & 111.4 & 129.7 & 98.6 & 82.3 & 40,6 & 85.0 \\
\hline $\begin{array}{c}\text { Hydrolysis } \\
\text { Rate } \\
(\%)\end{array}$ & 39 & 75 & 62 & 14 & 42 & 38 & 1 & 16 & 12 \\
\hline $\begin{array}{c}\text { Ethanol } \\
\text { Yields } \\
\left(\mathrm{mL} \cdot \mathrm{kg}^{-1}\right)\end{array}$ & 178 & 102 & 154 & 43 & 45 & 61 & 45 & 43 & 49 \\
\hline $\begin{array}{c}\text { Residual } \\
\text { Sugars } \\
\mathrm{mg}^{-1} \text {. }\end{array}$ & 35.8 & 15.4 & 20.5 & 27.1 & 14.4 & 14.6 & 16.9 & 8.8 & 2.0 \\
\hline
\end{tabular}

Note: In "Pretreatment" line: $\mathrm{Mi}=$ milling; St = steam; $\mathrm{Mw}=$ microwave. The values representing hydrolysis rates from steam pretreatments in Table 3 may have been higher due to some losses of biomass during autoclaving. Pressure shocks and foaming of alkaline suspensions caused small spills of biomass from the glass flasks. 
The results were different when analyzing the hydrolysis rates. All of the hydrolysis rates were higher in the steam and microwave pretreatments compared to the mechanical pretreatment.

\section{Bioethanol Production Potential}

After hydrolysate fermentation had taken place as a result of the enzymatic hydrolysis of pretreated biomasses by a selected ethanol and acid tolerant strain of $S$. cerevisiae, the highest ethanol concentration was achieved in the batches contacting avocado seeds (between $1.02 \%$ and $2.18 \%$ in fermentation media containing $10 \%$ biomass). The batch containing thermal-chemical pretreated avocado residues as the substrate for hydrolysis and fermentation gave lower ethanol yields (102 mg per gram biomass, dry matter) compared to batches that contained microwave pretreated and mechanical pretreated avocado seeds (154 mg and $178 \mathrm{mg}$, respectively). However, these results were not correlated to the sugars yields. During thermal-chemical pretreated biomass hydrolysis, higher sugar yields were obtained $\left(449.8 \mathrm{mg} \cdot \mathrm{g}^{-1}\right.$ ) compared to the microwave pretreated and mechanical pretreated avocado seeds $\left(237.9 \mathrm{mg} \cdot \mathrm{g}^{-1}\right.$ and 336.4 $\mathrm{mg} \cdot \mathrm{g}^{-1}$, respectively). Lower ethanol yields in the steam-alkaline pretreated biomasses and higher hydrolysis rates and sugar yields were obtained, which was explained by the accumulation of inhibitors in the biomass due to high temperatures $\left(140^{\circ} \mathrm{C}\right)$ of the steam applied to degrade the lignin. In the alkaline pretreatments several chemicals are generated, such as phenols, furans, phenol aldehydes, phenol ketones, and hydroxycarboxylic acids (glycolic acid, lactic acid) (Klinke et al. 2004). These chemicals have been indicated to inhibit the growth of yeasts and bacteria used in the fermentation of lignocellulosic sugars (Palmqvist et al. 2000).

The yields of the cocoa and peanut residual biomasses were $45 \mathrm{mg}$ and $61 \mathrm{mg}$ ethanol per gram of biomass, dry matter, respectfully. The ethanol yields in the case of these two biomass types were higher in the microwave than in the other pretreatments. The results of the sugar yields can help to apply other types of microorganisms for the fermentation of these types of hydrolysates. Qureshi et al. (2008) indicate that not only are furfural and hydroxymethylfurfural (HMF) not inhibiting, but they even stimulate butanol fermentation in Clostridium beijerinckii.

Regarding the kinetics of fermentation, most of the sugars were consumed in the first $24 \mathrm{~h}$ of fermentation. The concentrations of reducing sugars decreased in the first 24 $\mathrm{h}$ of fermentation from $10 \mathrm{mg} / \mathrm{mL}$ to $20 \mathrm{mg} / \mathrm{mL}$ to $0.8 \mathrm{mg} / \mathrm{mL}$ to $1.5 \mathrm{mg} / \mathrm{mL}$ in all fermentation media.

\section{Biomethane Production Potential}

After anaerobic digestion in the AMPTS II system, the BMP of the three residual biomass types was determined. The results representing the flow rate of methane produced during digestion are displayed in Fig. 3. The main production was registered in the first 5 to 10 days of anaerobic digestion in all cases.

The anaerobic digestion process registered a second peak of methane production after 15 days in the avocado residue without the addition of cellulases and after 20 days in the batch where the mixture of cellulolytic enzymes was added. Regarding the BMP, the biomass of avocado provided the highest yields (Fig. 4).

The methane yields established in this research are presented in Table 4. In all three cases, the cellulolytic enzymes improved the digestion of the residual biomass and led to an increase of methane production. The yields were higher in the batches where 
cellulases were added compared to the batches containing pretreated biomass as follows: $132 \%$ for avocado, $153 \%$ for cocoa, and $274 \%$ for peanuts.

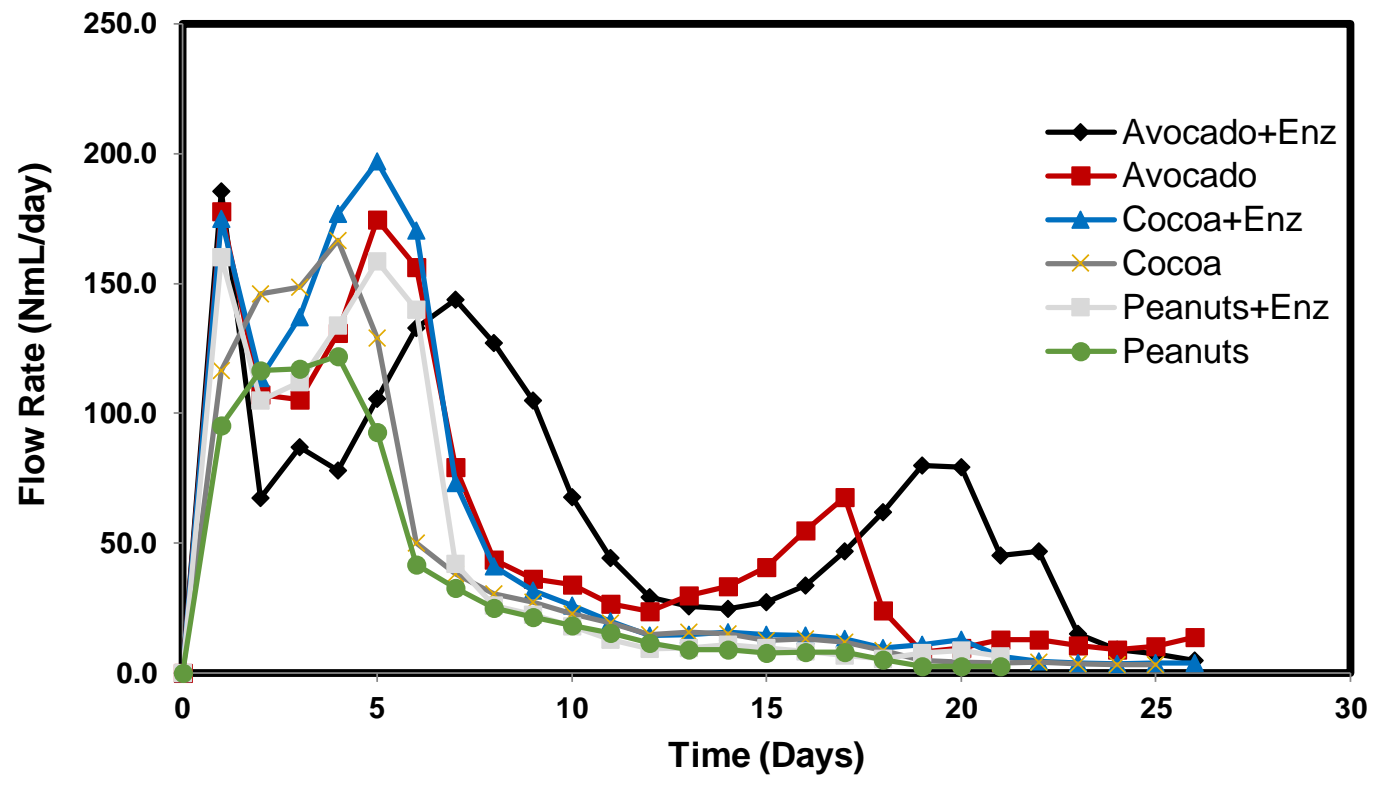

Fig. 3. Biomethane flow rate

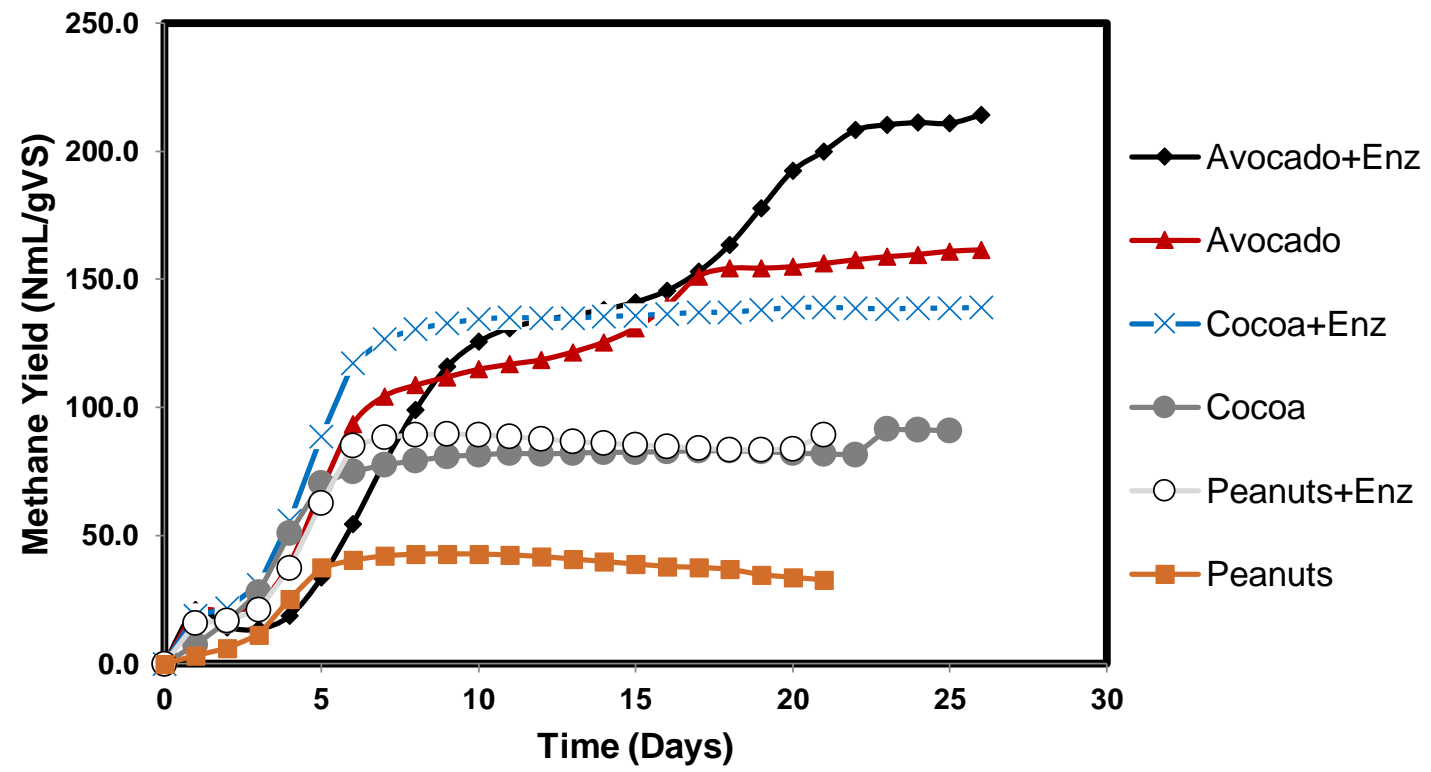

Fig. 4. Biochemical methane potentials established in AMPTS II system

The avocado seeds were the most productive energy carriers when comparing the methane yields obtained in the anaerobic digestion process of the three residual biomass types. The application of the thermal-chemical pretreatment (steam $+\mathrm{NaOH}$ ) increased the methane yields roughly $50 \%$ in the avocado seeds. If cellulases were added to the pretreated biomass, the yields increased 30\% compared to the pretreated biomass. An increase of methane yields was observed in the batches containing cellulases for the other two biomass types: $50 \%$ in cocoa pods and $170 \%$ in peanut shells compared to the 
thermal-chemical pretreated biomass. The higher yields of methane were obtained in the batches containing milled biomass, compared to the batches containing thermal-chemical pretreated biomass. The decrease in biogas yields was due to the formation of chemicals during the thermal-chemical pretreatment that affected the microbial growth (Palmqvist et al. 2000; Klinke et al. 2004; Qureshi et al. 2008).

Table 4. BMP of the Residual Biomass

\begin{tabular}{|c|c|c|c|c|}
\hline Biomass & Pretreatments & $\begin{array}{c}\text { Methane Yield } \\
(\text { NmL/gVS) }\end{array}$ & $\begin{array}{c}\text { Methane Yield } \\
(\text { NmL/g Biomass } \\
\text { Dry Matter })\end{array}$ & $\begin{array}{c}\text { Methane Yield } \\
\text { (NmL/g Biomass } \\
\text { Raw Material) }\end{array}$ \\
\hline \multirow{3}{*}{ Avocado seeds } & Milling & 105.7 & 87.7 & 75.3 \\
& Steam & 161.5 & 134.0 & 115.0 \\
& Steam + Cellulases & 214.2 & 177.8 & 152.5 \\
\hline \multirow{3}{*}{ Cocoa pods } & Milling & 168.6 & 126.5 & 106.6 \\
& Steam & 90.8 & 68.1 & 57.4 \\
& Steam + Cellulases & 139.0 & 104.3 & 87.9 \\
\hline \multirow{3}{*}{ Peanut shells } & Milling & 88.9 & 72.0 & 63.7 \\
& Steam & 32.6 & 26.4 & 23.4 \\
& Steam + Cellulases & 89.4 & 72.4 & 64.1 \\
\hline
\end{tabular}

\section{Assessment of Energy Production Potential in Cameroon}

Data obtained in this study are summarized in Table 5. The energy of liquid and gaseous biofuels obtained in the laboratory-scale experiments was compared to the caloric content of the residual biomass measured in a calorific bomb (ASTM D3286 1996; BS ISO 1928 2009). The technologies applied for the conversion of the three residual biomass types to liquid and gaseous biofuels provided different rates of energy recovery from the original feedstock. Avocado seeds were easily converted into biogas and by anaerobic digestion, roughly half of the total energy contained in the biomass $\left(15040 \mathrm{~J} \cdot \mathrm{g}^{-1}\right)$ was converted into methane $\left(7080 \mathrm{~J} \cdot \mathrm{g}^{-1}\right)$ and one third was converted into ethanol $\left(5287 \mathrm{~J} \cdot \mathrm{g}^{-1}\right)$ via lignocellulose hydrolysis and fermentation. In the cocoa and peanut residues, the energy conversion rates were much lower in all cases of lignocellulosic ethanol technology compared to anaerobic digestion technology conversion rates.

Table 5. Caloric Content Index Energy Potential

\begin{tabular}{|c|c|c|c|}
\hline Method Applied & \multicolumn{3}{|c|}{ Biomass } \\
\cline { 2 - 4 } & Avocado & Cocoa & Peanut \\
\hline $\begin{array}{c}\text { Calorimetric bomb, } \\
\text { Gross calorific value }\left(\mathrm{J} \cdot \mathrm{g}^{-1}\right) \text { dry matter }\end{array}$ & 15040 & 14300 & 14430 \\
\hline $\begin{array}{c}\text { Anarobic digestion, biomethane potential, } \\
(\mathrm{NmL} / \mathrm{g}) \text { biomass dry matter }\end{array}$ & 178 & 104 & 72 \\
$\begin{array}{c}\text { Energy, from biomethane* }\left(\mathrm{J} \cdot \mathrm{g}^{-1}\right) \\
\text { Percentage from gross calorific value }\end{array}$ & 7080 & 4153 & 2883 \\
\hline $\begin{array}{c}\text { Hydrolysis, fermentation to cellulosic ethanol, } \\
(\mathrm{mg} / \mathrm{g}) \text { biomass dry matter }\end{array}$ & 178 & 29 & 20 \\
\hline $\begin{array}{c}\text { Energy, from bioethanol } \\
\text { ** }\left(\mathrm{J} \cdot \mathrm{g}^{-1}\right)\end{array}$ & 5287 & 1812 & 145 \\
Percentage from gross calorific value & 35 & 13 & 10 \\
\hline
\end{tabular}


${ }^{\star}$ Note: Calculated for energy content of $39820 \mathrm{~kJ} / \mathrm{m}^{3}$; ${ }^{* *}$ Calculated for energy content of 29700 $J \cdot g^{-1}$

This study aimed to answer the following questions: what is the quantity of energy to be provided if the residues generated in Cameroon are converted to biofuels, and what is the share of this energy from the total energy production in Cameroon? Table 6 presents data about Cameroon regarding the average production of avocados, cocoa, and peanuts per year and the corresponding waste generated after processing their food products (Gaillard and Godefroy 1994; Eden Consulting \& Engineering Sarl 2012; Fonkeng_2014; Stoll et al. 2017). Based on the potential of the Cameroon economy and using the results regarding biomethane and bioethanol production potentials from the tested residues, the national potential of Cameroon to produce renewable energy as biofuels from avocado, cocoa, and peanut residues was calculated.

Table 6. Biofuels Potential/Energy Potential

\begin{tabular}{|c|c|c|c|c|}
\hline \multirow{2}{*}{ Product } & \multicolumn{2}{|c|}{$\begin{array}{c}\text { Production Per Year } \\
\text { (Tons) }\end{array}$} & \multicolumn{2}{c|}{ Biofuels Production Potential Per Year } \\
\cline { 2 - 5 } & Main Crops & Residues & Biomethane $\left(\mathrm{m}^{3}\right)$ & Bioethanol $(\mathrm{Kg})$ \\
\hline Avocado & $1,200,000$ & 28,800 & $4,406,400$ & $5,126,400$ \\
\hline Cocoa & 250,000 & 150,000 & $13,200,000$ & $9,150,000$ \\
\hline Peanut & 481,499 & 199,540 & $12,770,560$ & $9,777,460$ \\
\hline Total & $1,931,499$ & 378,340 & $30,376,960$ & $24,053,860$ \\
\hline \multicolumn{2}{|c|}{ Energy Potential (MWh) } & 334,147 & 198,444 \\
\hline \multicolumn{2}{|c|}{ Energy Potential (toe) } & & 28,730 & 17,062 \\
\hline
\end{tabular}

${ }^{*}$ Note: $1 \mathrm{~m}^{3}$ methane $=11 \mathrm{kWh} ; 1 \mathrm{~kg}$ ethanol $=8.25 \mathrm{kWh} ;{ }^{* *} 1 \mathrm{MWh}=85.98 \mathrm{ktoe}$

When the data displayed in Table 6 were compared to the total energy delivered nationwide in Cameroon, a clearer image was constructed on the potential of these residues generated in the Cameroonian economy to be converted into gaseous and liquid biofuels. Based on the gross electricity consumption of 6.2 TWh in Cameroon, the biogas that can be produced from the avocado, cocoa, and peanut residues can cover $5.39 \%$ and the ethanol can cover $3.19 \%$ from the entire electricity consumed. A more realistic scenario is the use of biomethane and bioethanol in the transportation sector in Cameroon. Available public data regarding energy statistics in Cameroon indicate projections of approximately 1000 ktoe oil consumed in transportation annually (AFREC 2015). Consequently, the biomethane production potential of 28 ktoe can replace approximately $28 \%$ from oil consumption in transportation and the bioethanol that can be produced from avocado, cocoa, and peanut residues can replace $17 \%$ from oil consumption in transportation.

These calculations were based on the results obtained in a laboratory-scale and on public data available online regarding the energy sector in Cameroon. The figures may change when the second-generation biogas and bioethanol is scaled-up to a pilot and commercial-scale according to dynamics of energy production and consumption in Cameroon. In conclusion, this study demonstrated the possibility to convert residues in gaseous and liquid biofuels and indicated the importance of organic residues as feedstock for renewable energy production. 


\section{CONCLUSIONS}

1. The residues generated after the processing of the main products in avocado, cocoa, and peanut crops were converted to second-generation gaseous biofuels (biogas) and liquid biofuels (ethanol).

2. The energy conversion rate was higher when anaerobic digestion technology was applied to convert the tested biomass to methane compared to the conversion rate when lignocellulosic ethanol technology was applied.

3. Using avocado seeds as feedstock, high yields of methane and ethanol were produced. The availability of cocoa pods and peanut shells in the Cameroon economy in large quantities makes these residues important feedstock for renewable energy production.

4. The share of energy potential of the tested residual biomass is important when compared to the fossil fuel consumption in Cameroon for transportation. In addition, the tested biomass represented a potential feedstock for electricity production when the energy potential was compared to Cameroon gross electricity consumption.

\section{ACKNOWLEDGMENTS}

The authors are grateful for the support of the program "Eugen Ionescu" 20172018, sponsored by the Romanian government for Ph.D. research stages.

\section{REFERENCES CITED}

ASTM D3286-96 (1996). "Standard test method for gross calorific value of coal and coke by the isoperibol bomb calorimeter (Withdrawn 2000)," ASTM International, West Conshohocken, PA.

Azap, N. (2008). "Cameroun: Les paradoxes de l'avocatier à l'Ouest [Cameroon: The paradoxes of avocado in the west]," Le Messenger, (https://fr.allafrica.com/stories/200807030521.html), Accessed 01 Dec 2018.

Bioprocess Control A.B. (2016). Automatic Methane Potential System-AMPTS II. Operation and Maintenance Manual, Bioprocess Control A. B., Lund, Sweden.

BS ISO 1928 (2009). "Determination of gross calorific value by the bomb calorimetric method and calculation of net calorific value," British Standards Institution, London, UK.

Eden Consulting \& Engineering Sarl (2012). Etude des Filières Vivrières Destinées à l'Exportation vers le Marché Européen [Study of Food Chains Towards Export to the European Market] (No. 022/MINEPAT/PASAPE/DP3/2012), Cameroon-European Union Cooperation, Yaoundé, Cameroon.

EN ISO 13906 (2008). "Animal feeding stuffs - Determination of acid detergent fibre (ADF) and acid detergent lignin (ADL) contents," International Organization for Standardization, Geneva, Switzerland.

Fonkeng, E. E. (2014). Cocoa Yield Evaluation and Some Important Yield Factors in Small Holder Theobroma cacao Agroforests in Bokito- Centre Cameroon, Master's Thesis, University of Dschang, Dschang, Cameroon. 
Gaillard, J. P., and Godefroy, J. (1994). "L'avocatier [The avocado]," in: Le Technicien Dágriculture Tropicale [The Tropical Agriculture Technician], R. Coste (ed.), Maisonneuve et Larose, Paris, France, pp. 190-192.

Ghose, T. K. (1987). "Measurement of cellulase activities," Pure and Applied Chemistry 59(2), 257-268. DOI: 10.1351/pac198759020257

Girod, J. (1994). L'énergie en Afrique: La Situation Énergétique de 34 Pays de l'Afrique Subsaharienne et du Nord [Energy in Africa: The Energy Situation of 34 Countries in North and the Sub-Saharan Africa] (Report No. 196-49e), Karthala, Paris, France.

Gonzalez, R., Jameel, H., Chang, H., Treasure, T., Pirraglia, A., and Saloni, D. (2011). "Thermo-chemical pulping as a pretreatment for agricultural biomass for biochemical conversion," BioResources 6(2), 1599-1614. DOI: 10.15376/biores.6.2.1599-1614

Ioelovich, M. (2015). "Recent findings and the energetic potential of plant biomass as a renewable source of biofuels - A review," BioResources 10(1), 1879-1914. DOI: 10.15376/biores.10.1.

Klinke, H. B., Thomsen, A. B., and Ahring, B. K. (2004). "Inhibition of ethanolproducing yeast and bacteria by degradation products produced during pretreatment of biomass," Applied Microbiology and Biotechnology 66(1), 10-26. DOI: 10.1007/s00253-004-1642-2

Kumar, R., Singh, S., and Singh, O. V. (2008). "Bioconversion of lignocellulosic biomass: Biochemical and molecular perspectives," J. Ind. Microbiol. Biotechnol. 35(5), 377-391. DOI: 10.1007/s10295-008-0327-8

Meughoyi, C. T. (2018). "Improved seeds and agricultural productivity of family farms in Cameroon," in: Building a Resilient and Sustainable Agriculture in Sub-Saharan Africa, Palgrave Macmillan, Cham, Switzerland, pp. 15-35. DOI: 10.1007/978-3-31976222-7_2

Miller, G. L. (1959). "Use of dinitrosalicylic acid reagent for determination of reducing sugar," Analytical Chemistry 31(3), 426-428. DOI: 10.1021/ac60147a030

NAVTI Foundation Canada (2016). Amélioration et Valorisation de la Petite Production Locale D'avocat à Bafoussam, Province de l'Ouest Cameroun Afrique Centrale [Improvement and Recovery of the Avocado Small Local Production of Bafoussam, West Region of Cameroun, Central Africa], Organisme de Coopération International [Organization for International Cooperation ], NAVTI Fondation, Québec Canada.

Nkue, V., and Njomo, D. (2009). "Analyse du système énergétique Camerounais dans une perspective de développement soutenable [Analysis of Cameroon's energy system from a sustainable development perspective]," Revue de l'Énergie 588, 24-31.

Palmqvist, E., and Hahn-Hägerdal, B. (2000). "Fermentation of lignocellulosic hydrolysates. I: Inhibition and detoxification," Bioresource Technology 74(1), 17-24. DOI: 10.1016/s0960-8524(99)00160-1

Qureshi, N., Badal, C. S., Ronald, E. H. M., and Cotta, A. (2008). "Removal of fermentation inhibitors from alkaline peroxide pretreated and enzymatically hydrolyzed wheat straw: Production of butanol from hydrolysate using Clostridium beijerinckii in batch reactors," Biomass and Bioenergy 32(12) 1353-1358. DOI: 10.1016/j.biombioe.2008.04.009

Sluiter, A., Hames, B., Hyman, D., Payne, C., Ruiz, R., Scarlata, C., Sluiter, J., Templeton, D., and Wolfe, J. (2005). Determination of Total Solids in Biomass and Total Dissolved Solids in Liquid Process Samples (NREL/TP-510-42621), National Renewable Energy Laboratory, Golden, CO. 
Stoll, L., Niemenak, N., Bisping, B., and Lieberei, R. (2017). "German cacao of Cameroon - New facts on a traditional variety fallen into oblivion," Journal of Applied Botany and Food Quality 90, 274-279. DOI: 10.5073/JABFQ.2017.090.034

VDI 4630 (2006). "Fermentation of organic materials: Characterization of the substrate, sampling, collection of material data, fermentation test," The Association of German Engineers, Dusseldorf, Germany.

Vintila, T., Sumalan, R., Popa, N. F., Dragomirescu, M., Ionel, I., and Sala, F. (2019). "Microwave and steam mediated pretreatments of sweet sorghum bagasse: Focus on energy efficiency," BioResources Accepted for publication.

$\mathrm{Xu}, \mathrm{J} ., \mathrm{Li}, \mathrm{M}$., and Sun, R. (2018). "Successive fractionations of hemicelluloses and lignin from sorghum stem by sodium hydroxide aqueous solutions with increased concentrations," BioResources 13(2), 2356-2373. DOI: 10.15376/biores.13.2.23562373

Article submitted: December 10, 2018; Peer review completed: March 4, 2019; Revised version received: March 18, 2019; Accepted: March 20, 2019; Published: March 22, 2019.

DOI: 10.15376/biores.14.2.3731-3745 